\title{
Influence of chosen technical constraints on stability of 3D geological model-based schedule in a complex longwall operation
}

\author{
Leszek Malinowski ${ }^{*}$ \\ ${ }^{1}$ Mineral and Energy Economy Research Institute, 7A Wybickiego St., 31-261 Kraków, Poland
}

\begin{abstract}
In Polish underground mining digital 3D geological models and mine structure models are becoming popular as an aid in creating design and schedules of mine workings. Article highlights development made in generating and optimizing mining operations. Having created a model it is possible to test schedule scenarios using a number of constraints. One of the constraint limiting coalmines is ventilation, which may be magnified by high content of methane in coal deposits. In this article two methods of introducing ventilation constraints have been presented. One limits number of longwall shearers working simultaneously in excavations ventilated by the shaft. The other limits tonnage of coal which can be extracted in each ventilation zone. Scenarios governed by the second method turned out to result in more stable exploitation than a base scenario. More precise calculations are possible if a model contains an accurate prognosis of methane emissions that would be caused by extraction of the coal deposit. The aim of the paper is to present possibilities of analysing and upgrading mining operations with the help of digital solutions.
\end{abstract}

\section{Introduction}

Despite growing environmental awareness regarding the climate change and how it is influenced by using fossil fuels for generating energy, coal mining remains a major branch of industry in many countries, including Poland. In 2018 nearly $6481 \mathrm{mln} \mathrm{Mg}$ of hard coal was mined worldwide, though these numbers are in decline since 2016 [1]. Hard coal in the industry has two dominant applications: generating electricity and creating coke for steel production. In $201738.1 \%$ of world's electricity, and 78,7 \% of polish electricity was produced by burning coal [1], while $71.5 \%$ of world's steel production was based on using coking coal in a basic oxygen method [2].

Underground coalmines are enterprises that require high investments and need to operate for long periods of time to start turning in profits. Mine-power plant complexes in Poland have estimated discounted paybacks amounting to even 31 years [3]. Because of that mining companies need to carefully plan their operations in order to reduce cost of exploitation and optimize quality and/or quantity of extracted material. In a broad sense, problems of optimization of these issues are widely covered in scientific literature and will

\footnotetext{
*Corresponding author: malinowski@meeri.pl
} 
be briefly described below.

Process of planning mining workings require calculating and visualising their geological, technical and economic conditions. It can be aided by creating a digital, threedimensional geological model as well as a model of planned mine structure. In recent years new generation of geological modelling and mine planning software has been gaining in popularity in Poland - geological model is being used in the underground copper mines of KGHM Polska Miedź SA [4], as well as in the LW Bogdanka SA coalmine [5]. They are also currently being introduced in JSW SA, a company that mines coking coal in heavily faulted deposits of Upper Silesian Coal Basin.

Limited information regarding optimization of an underground mining, that would involve accurate geological data and limitations on access and development drivage or other local constraints, can be found in the scientific literature. The most similar model found was created by Rocchi et al. for one of the Australian mines [6]. The papers discussing this topic cover mining operations using technology appropriate for conditions of their deposits, which vary between sites.

In this paper an attempt was made to calculate how much do ventilation and transport constraints interrupt the mining schedule. To achieve that a structural model of an underground mine was built and set in conditions similar to those found in polish hard coal mines, where most of the coal is mined from seams over $500 \mathrm{~m}$ below ground level, longwall panel shapes are limited by faults, and exploitation takes place in multiple seams [7]. To estimate the volume of exploitation, one of the previously created geological models of a seam coal deposit was applied.

\section{Optimization of mining processes}

Ideas on how to optimize an underground mining plan can be found in a number of papers. Mining enterprise can maximize effectiveness of a number of subprocesses.

Alford et al. mentions six major areas of optimization [8]:

- parameters of an infill drilling, which aim to acquire core data sufficient to properly characterize deposit location and quality of material at minimum cost [9];

- cut-off grade, which, if correctly calculated, maximizes the Net Present Value of a mining operation [10];

- exploitation method, choice of which needs to be made considering the shape of the deposit, strength of the rock mass and geological hazards;

- spatial location and shape of a single decline, which needs to be designed in a way allowing it to remain as short as possible while avoiding potential obstacles and hazardous zones maintaining an acceptable dip [8];

- design of a development tunnel network that is optimized to minimize cost of development, haulage and ventilation while allowing the chosen volume of exploitation;

- exploitation and development schedule, which should allow a stable material extraction and minimize cost of machine park lease and workforce.

This article focuses on the last two areas, as they can be strongly aided by using geological model. Network design requires accurate geological data, because discontinuities change costs of both roadway driving and support. Fault areas increase hazards and require additional support, while coal seams and soft rocks let miners cut coal using roadheaders, which is significantly cheaper than drill and blast [11]. In development scheduling geological data is needed to properly assign available equipment to working conditions and calculate costs and revenues, as well as to add safety-related tasks where necessary.

Mathematical solutions optimizing mine design have been presented in several papers so far. Brazil et al. in [12] propose using a model to estimate an optimal positioning of 
transport roadways to minimize total transport and development cost. It is being modelled as a three-dimensional network. This model assumes a mine with transport shaft of fixed position but variable depth, fixed mining areas and their expected tonnage and variable costs of haulage, which depends on transported tonnes, and development which is based on tunnel meters mined. It also incorporates a constraint coming from a maximum inclination of the transport roadways and minimum radiuses of turning circles. Same authors propose a software solution for this model $[13,14]$, which takes into consideration some geological and technical aspects by avoiding areas unfavourable for development, such as fault zones or areas too close to existing workings. They are, however, focused on ore mining and therefore do not take into account big differences in cost between roadways dug in a rock mass and a coal seam.

Optimizing the mining schedule can be approached in a number of ways. Brzychczy and Lipiński propose using an evolutionary algorithm to achieve multiple targets of a model [15]. Their solution is an algorithm calculating the matrix of longwall faces and available equipment. Machines' availability and performance were extracted from machinery logs using Data Mining techniques. They incorporated two objective functions, minimum deviation of the net output from the given plan and minimum standard deviation of the net output. This results in an optimized assignment of the longwall equipment to exploitation task. Then they may create an activity network and use it to get information about assumed exploitation duration and expected monthly value of output coal along with its standard deviation. This solution was also made into a digital application [16].

In recent years many researchers proposed solutions using Mixed-Integer Programming (MIP), which is a type of Linear Programming (LP). LP model consists of a linear objective function and a number of linear constraints. On the contrary, Integer Programming consists of integer values, represented by zeroes and ones. This kind of solutions are used to represent indivisible entities, such as workforce or a number of machines. Model is called MIP if it involves both linear and integer variables [17].

Carlyle and Eaves used an MIP-based model to decide between a number of mining variables in a new area of Stillwater mine. This solution resulted in estimating the most profitable mining scenario [18]. Similar solution is presented by Nehring and Topal [19], showing a raise of expected profit compared to a manual schedule. Even more advanced model presented in [20] took into consideration uncertainty of geological information as an associated risk.

To achieve the optimal solutions, proposed models consist of thousands of decision variables [18] what suggests these methods are time-consumable and preferable for longterm strategic planning done before the start of the operation.

\section{Construction of the model and its constraints}

In an underground coalmine using longwall system optimization of schedule is highly constraint, just as is exploitation [7]. Creating a feasible model requires incorporating the most important of these constraints. The Aim of the work, which is presented in this paper, was to look into ways of including those constraints in a modelled schedule. To achieve that a structural model of planned mine workings, which were similar to those found in polish mines, was used. It was built using Deswik.CAD and Deswik.Sched software. Input data were imported from the Minescape geological model previously created in Mineral and Energy Economy Research Institute of Polish Academy of Sciences.

Geological data was used to:

a) Create longwalls layout in the seams. In this process major fault areas were avoided, while smaller faults caused derations of longwalls;

b) Calculate the output volume and tonnage, which was necessary to calculate the 
compatibility of a schedule to established target.

Major faults created in the geological model divided the mine area into 3 zones, which were given the numbers I, II and III (Fig. 1). Each of these zones was assigned to one of the ventilation shafts. Mass of coal contained in modelled longwalls of those zones amounted to:

Zone I $-16.7 \%$ of total coal output, mined from 3 seams,

Zone II $-46.3 \%$ of total coal output, mined from 12 seams,

Zone III $-37.0 \%$ of total coal output, mined from 12 seams.

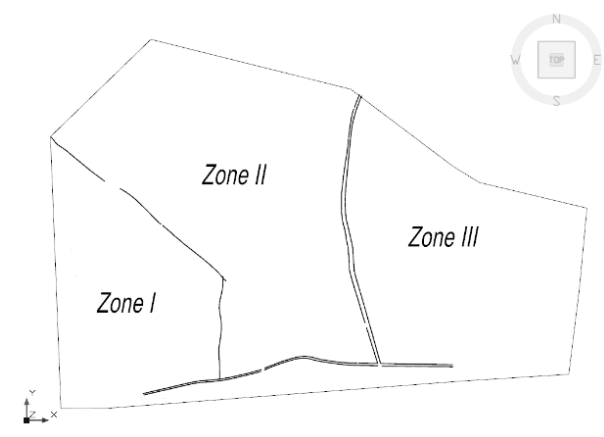

Fig. 1. Mining area and major faults of the mined deposit.

\section{Model assumptions}

In the model certain assumptions and approximations were made:

a) 6 longwalls and 16 roadheaders can work simultaneously in the mine. These numbers, which are similar to ones characterizing large mining enterprises, were assumed to enable bigger elasticity in building constraints;

b) Areas outside of the modelled seams consist of uniform rock mass, which has a bulk density of $2 \mathrm{Mg} / \mathrm{m}^{3}$;

c) If heading face mined by roadheader is $30 \%$ or more outside of the seam, roadheaders slow down by $30 \%$, and longwall shearers slow down by $10 \%$. If face is over $60 \%$ outside of the seam, roadheaders slow down to $60 \%$, and longwall shearers slow down to $60 \%$ of assumed base rates;

d) Exploitation of each $\mathrm{Mg}$ of coal results in emission of $15 \mathrm{~m}^{3}$ of methane. It is a value slightly higher than the average in polish mines in 2011 [21];

e) Longwalls located in lower seams cannot be mined before those located directly above are finished. Modelled seams are located close to each other, therefore failing to obey this rule could result in damaging deposit structure;

f) Only shafts are constraining for the exploitation in terms of ventilation;

g) Volume of air outflow of the shaft is equal to the summary volume of the air leaving longwalls assigned to the shaft;

h) Mine has 3 ventilation shafts: one main shaft, with fan station capacity of $20000 \mathrm{~m}^{3} / \mathrm{min}$; and two minor shafts with fan station capacities of $10000 \mathrm{~m}^{3} / \mathrm{min}$. These values are similar to those found in polish mines [22];

i) Base longwall advance has a value of $5 \mathrm{~m} /$ day, while base tunnel advance has a value of $9 \mathrm{~m} /$ day. These values are similar to those found in most productive coalmines in Upper Silesian Coal Basin [23];

j) Mine aims to extract $300000 \mathrm{Mg}$ of coal per month.

Model has a global constraint of 33000 tonnes of material per day, which can be caused either by limited capacity of a hoisting shaft or a processing plant. 


\section{Ventilation constraints}

Underground mine working areas need to be properly ventilated to provide safe working conditions for miners. Additionally, many of the polish underground coalmines have to deal with methane hazard, which is a risk of an outflow and combustion of methane stored in coal seams [24]. Because of that, ventilation shafts can become constraining factors for exploitation schedule. Mine planning software makes it possible to implement ventilation constraints in multiple ways.

In this exercise two of them were used: maximum concurrent resources working in the same area and maximum extraction value. For each of them two scenarios were created by assigning the main shaft to either zone II or III (Table 1). Zone I had a minor shaft assigned in every scenario, as it contained significantly less coal than the rest. In addition there was created a base scenario, in which schedule was not constraint by ventilation.

Table 1. Created scenarios of exploitation schedule.

\begin{tabular}{|c|c|c|}
\hline Scenario name & Type of ventilation constraint & Zone assigned to a major shaft \\
\hline Base scenario & none & none \\
\hline Scenario 1 & Maximum concurrent resources & II \\
\hline Scenario 2 & Maximum concurrent resources & III \\
\hline Scenario 3 & Maximum extraction value & II \\
\hline Scenario 4 & Maximum extraction value & III \\
\hline
\end{tabular}

\subsection{Maximum concurrent resources}

Generating a schedule in mine planning software requires creating a number of entities called resources, which conduct mining operations, and assigning them to tasks located in three-dimensional space. Resources can represent either units of workforce, such as brigades, or major mining machinery, such as longwall shearers, roadheaders, continuous miners etc.

Maximum concurrent resources method is constraining the exploitation by limiting the number of resources, which can be simultaneously assigned to tasks belonging to one group. In this case groups were created by giving mining tasks an attribute of shaft they should be ventilated by. Using this rule two scenarios were created (Table 2).

Table 2. Ventilation constraints applied to scenarios 1 and 2.

\begin{tabular}{|l|c|c|c|}
\hline \multirow{2}{*}{ Zone } & \multicolumn{3}{|c|}{ Maximum number of shearers operating in zone } \\
\cline { 2 - 4 } & I & II & III \\
\hline Scenario 1. Main shaft belongs to zone II & 2 & 4 & 2 \\
\hline Scenario 2. Main shaft belongs to zone II & 2 & 2 & 4 \\
\hline
\end{tabular}

\subsection{Exploitation limited by required airflow}

For the creation of this constraint it is assumed that volume of air that needs to flow through ventilation shaft is proportional to the volume of emitted methane. In this example it is also proportional to a coal output assigned to that shaft. For calculation of the airflow required in the longwall, the equation of maximum acceptable methane emission was used [25]. 


$$
V_{k r}=\frac{V_{p} \cdot c_{m} \cdot k}{100 \cdot n}+\frac{V_{L}\left(\frac{c_{m}}{n}-c_{p}\right)}{100-\frac{c_{m}}{n}}-V_{D\left(C H_{4}\right)},
$$

where $V_{k r}$ is a maximum acceptable methane emission, $\mathrm{m}^{3} / \mathrm{min} ; V_{p}$ is an airflow in the longwall working, $\mathrm{m}^{3} / \mathrm{min} ; V_{L}$ is a volume of air entering the longwall working due to support ventilation; $c_{m}$ is an acceptable methane content in the air current leaving the longwall heading, $c_{m}=1.5 \% ; c_{p}$ is a methane content in air current entering the longwall working; $k$ is an air velocity unevenness factor, $k=0.85 ; n$ is a methane emission unevenness factor, $n=1.55$; and $V_{D\left(C_{4}\right)}$ is a volume of methane entering the longwall face from other sources, $\mathrm{m}^{3} / \mathrm{min}$.

Assuming no support ventilation is being used and no methane is entering the longwall working, total acceptable methane emission amounts to $231.7 \mathrm{~m}^{3} / \mathrm{min}$ for a main and $115.9 \mathrm{~m}^{3} / \mathrm{min}$ for each of minor shafts. Given this values, three constraints were added into a model: maximum coal extracted from workings assigned to main shaft amounts to $22245 \mathrm{Mg}$ /day, while workings assigned to each of minor shafts can extract up to $11122 \mathrm{Mg} /$ day.

\section{Results}

To measure the stability of created schedules an average difference between monthly coal extraction for these scenarios and monthly target was calculated by using following formula:

$$
\alpha=\frac{\sum_{i=1}^{n} \frac{\left|M_{\text {scenario }}-M_{\text {targ et }}\right|}{M_{\text {targ et }}}}{n} .
$$

To measure the degree of achieving the target, the formula below was used:

$$
\beta=\frac{\sum_{i=1}^{n} \frac{\left|M_{\text {scenario }}-M_{\text {targ et }}\right|}{M_{\text {target }}}}{n},
$$

where $\alpha$ is an average difference between an actual and a target tonnage, $\% ; M_{\text {scenario }}$ is a coal output generated each month in the scenario, thou. $\mathrm{Mg} / \mathrm{month} ; \mathrm{M}_{\text {target }}$ is a monthly target for coal output, thou. $\mathrm{Mg} / \mathrm{month} ; n$ is a number of months in the analysed period; and $\beta$ is a degree in which target has been achieved, $\%$.

Monthly coal output of modelled scenarios and target output have been depicted in Fig. 2.

For analysis purposes a 10-year period was chosen to avoid disruptions coming from the actual end of each schedules, which are a result of limited number of longwalls set up in the model. Results are presented in Table 3.

None of the created scenarios managed to match the target. It is not a reason to deem them incorrect - this target was set up arbitrarily, its main purpose was to guide the algorithm in creation of the schedule. Were the model created for an actual mining operation, these results would suggest that assigning additional resources or loosening one of the constraints is necessary. 
Scenario 1 and 2 are highly unstable and have the lowest degree of plan implementation. It is likely caused by the incompatibility of the mining shafts' capacities and a deposit structure. Zone II and III have a similar amount of coal stored in the deposits, but one of them in each scenario is ventilated by a minor shaft. This results in blocking the exploitation conducted in that zone from operating at full speed. Low performance of these scenarios could be mitigated by a slight correction of the mine structure design, which would allow to assign more of the longwalls to the major shaft.
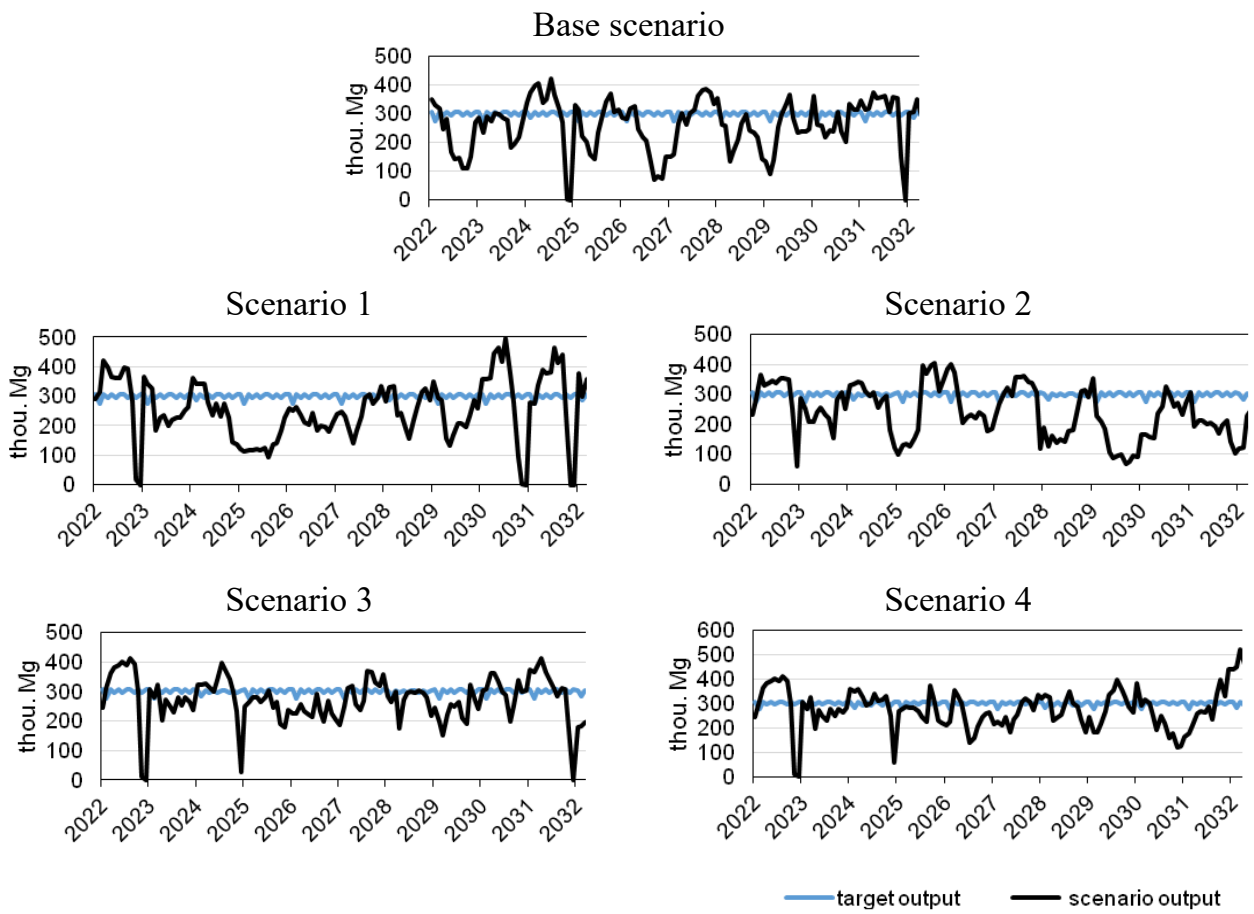

Fig. 2. Graphs of monthly coal output in modelled scenarios [thou. Mg].

Table 3. Results of simulation - schedule stability and plan implementation degree.

\begin{tabular}{|r|r|r|r|r|r|}
\hline & Base scenario & Scenario 1 & Scenario 2 & \multicolumn{1}{c|}{ Scenario 3 } & Scenario 4 \\
\hline$\alpha$ & $23.50 \%$ & $30.38 \%$ & $29.93 \%$ & $19.11 \%$ & $22.77 \%$ \\
\hline$\beta$ & $87.79 \%$ & $84.37 \%$ & $78.14 \%$ & $91.39 \%$ & $91.74 \%$ \\
\hline
\end{tabular}

Scenarios 3 and 4 are moderately stable and result in better plan implementation than the base scenario. After analysing the schedules the conclusion as made that this effect was caused by limited development resources and a global constraint of the daily coal output. In the base scenario coal output was less constraint, which resulted in high exploitation in the first few years. It was however diminished by the low-output periods in years 2026, 2028 and 2029. Those were caused by the exploitation being carried faster than the development, which in result created periods when an insufficient number of longwalls was ready to work. The global constraint of $33000 \mathrm{Mg}$ /day made it impossible for a schedule to make up for the loss. On the other hand, constraints in scenarios 3 and 4 forced the exploitation to be more modest from the very beginning what resulted in avoiding most of the low extraction periods. 


\section{Conclusions}

Three-dimensional modelling techniques became popular in mining industry as they gave access to geological and technical data regarding the mining operation in a much more convenient form than $2 \mathrm{D}$ vector maps.

In addition, they allow the users to set a connection between the model entity, its location in the deposit and corresponding data, such as quality of the material, its physical parameters and potential hazards and obstructions. This opens new opportunities in data analysis, which is crucial for operating in growing competitiveness of mining industry. Unified method of storing geological, technical and economic data and functions provided by modern software allow to optimize mining operations in deeper ways than it was possible before.

Methods of introducing constraints presented in his article turn in satisfying results for operations having limited information about potential methane emission. Were the model filled with such data, it could have been introduced a constraint limiting methane emission volume in time as a geological data-based variable instead of an estimated constant value. This solution is to be tested in the further research.

$3 \mathrm{D}$ mine workings model is deterministic, as it assigns one value of each of the parameters to each task, thus it does not allow to directly incorporate risks and uncertainties to the mining schedule. Therefore it should not be used as a substitute for stochastic models. However, compared to stochastic solutions it turns in fast results and therefore allows users to analyse multiple complex scenarios, which is a highly valuable feature in constantly changing conditions of mining enterprise.

This research was done on behalf of the Division of Mineral Resources Acquisition of the Mineral and Energy Economy Research Institute. Used model was created due to Institute's continuous cooperation with Deswik Software Systems Pty Ltd.

\section{References}

1. Mineral and Energy Economy Research Institute. (2018). Hard coal mining in Poland in 2017. Cracow.

2. World Steel Association. (2019). World Steel in Figures 2018. Brussels.

3. Michalak, J. (2012). Comparative analysis of coal and nuclear investment profitability. Energy Policy Journal, 15(4), 187-199.

4. Wasilewska-Błaszczyk, M. \& Mucha, J. (2017). Geochemical modeling of the Cu-Ag deposits from the Lubin-Głogów Copper District (Poland) supported by lithological modeling. Mineral Resources Management, (33), 63-78. http://doi.org/10.1515/gospo-2017-0049

5. Kowalczyk, I., Galica, D., Dyczko, A., Kołomański, D., \& Mól, D. (2016). The geological model of deposit - the method of construction, role and meaning in the process planning and scheduling of exploitation. The Bulletin of The Mineral and Energy Economy Research Institute of the Polish Academy of Sciences, (92), 413-425.

6. Rocchi, L., Carter, P., \& Stone, P. (2011). Sequence optimization in longwall coal mining. Journal of Mining Science, 47(2), 151-157. https://doi.org/10.1134/s106273914702002x

7. Zorychta, A., \& Burtan, Z. (2008). Uwarunkowania i kierunki rozwoju technologii podziemnej eksploatacji złóż w polskim górnictwie węgla kamiennego. Gospodarka Surowcami Mineralnymi, 24(1/2).

8. Alford, C., Brazil, M., \& Lee, D.H. (n.d.). Optimisation in Underground Mining. Handbook Of Operations Research In Natural Resources, 561-577. http://doi.org/10.1007/978-0-387-71815$\underline{6} \underline{30}$ 
9. Boucher, A., Dimitrakopoulos, R., \& Vargas-Guzmán, J. A. (2005). Joint Simulations, Optimal Drillhole Spacing and the Role of the Stockpile. Quantitative Geology and Geostatistics, 35-44. https://doi.org/10.1007/978-1-4020-3610-1_4

10. Poniewierski, J., MacSporran, G., \& Sheppard, I. (2003). Optimization of Cut-Off Grade at Mount Isa Mines Limited's Enterprise Mine. In Mine Planning and Equipment Selection (pp. 531-538). Kalgoorlie, Western Australia.

11. Copur, H., Ozdemir, L., \& Rostami, J. (1998). Roadheader applications in mining and tunneling industries. Mining Engineering, (50), 38-42.

12. Brazil, M., Lee, D., Rubinstein, J., Thomas, D., Weng, J., \& Wormald, N. (2002). A network model to optimise cost in underground mine design. Transactions of the South African Institute of Electrical Engineers, (93), 97-103.

13. Brazil, M. \& Grossman, P.A. (2008) Access layout optimisation for underground mines. In Australian Mining Technology Conference (pp. 119-123). Twin Waters, Queensland.

14. Brazil, M., Lee, D., Rubinstein, J.H., Thomas, D.A., Weng, J.F., \& Wormald, N.C. (2004) Optimisation in the design of underground mine access. In Uncertainty and Risk Management in Orebody Modelling and Strategic Mine Planning (ed: R Dimitrakopoulos) (pp.121-124). The Australasian Institute for Mining and Metallurgy Spectrum Series.

15. Brzychczy, E., \& Wnuk-Lipiński, P. (2013). Knowledge-based modeling and multi-objective optimization of production in underground coal mines. AGH Journal of Mining and Geoengineering, 37(1), 13. https://doi.org/10.7494/mining.2013.37.1.13

16. Brzychczy, E. (2011). The planning optimization system for underground hard coal mines. Archives of Mining Sciences, 56(2), 161-178.

17. Little, J., \& Topal, E. (2011). Strategies to assist in obtaining an optimal solution for an underground mine planning problem using Mixed Integer Programming. International Journal of Mining and Mineral Engineering, 3(2), 152. https://doi.org/10.1504/ijmme.2011.042429

18. Carlyle, W.M., \& Eaves, B.C. (2001). Underground Planning at Stillwater Mining Company. Interfaces, 31(4), 50-60. https://doi.org/10.1287/inte.31.4.50.9669

19. Nehring, M., \& Topal, E. (2007). Production schedule optimisation in underground hard rock mining using mixed integer programming. In Project Evaluation Conference 2007 (pp. 169-175). Melbourne, VIC, Australia.

20. Carpentier, S., Gamache, M., \& Dimitrakopoulos, R. (2016). Underground long-term mine production scheduling with integrated geological risk management. Mining Technology, 125(2), 93-102. https://doi.org/10.1179/1743286315y.0000000026

21. Grzybek, I., \& Respondek, A. (2012). Polskie doświadczenia w zakresie odgazowania złóż węgla. Wiadomości Naftowe i Gazownicze 2012, (5), 4-10.

22. Krause, E., \& Gajdowska, M. (2013). Prognozowany dopływ metanu do szybów wydechowych kopalń węgla kamiennego o najwyższej metanowości w latach 2013-2020. Górnictwo i Geologia, (8), 61-74.

23. Turek, M. (2008). Postęp dobowy ścian ważnym składnikiem procesu restrukturyzacji technicznej. Przeglad Górniczy, 64(2), 3-9.

24. Szlązak, N., \& Szlązak, J. (2013). Wentylacja wyrobisk ścianowych w kopalniach węgla kamiennego, w warunkach zagrożeń metanowego i pożarowego. Górnictwo i Geologia, (8), 115131.

25. Koptoń, H., \& Wierzbiński, K. (2016). Analiza wentylacyjno-metanowa, jako narzędzie dla bieżącej oceny poziomu zagrożenia metanowego w kopalniach węgla kamiennego. Systemy Wspomagania w Inżynierii Produkcji - Górnictwo: perspektywy i zagrożenia, (13), 267-278. 